\title{
И.А. Филина
}

\section{НЕГАТИВНЫЕ ТРАДИЦИИ И НОВАЦИИ В СОВРЕМЕННОЙ ДУХОВНОСТИ}

Духовность всегда многомерна, ее смысл, наполнение, составляющие во все времена взаимообусловлены и переплетены. Тем не менее, ключевыми моментами в осмыслении духовного потенциала любого общества всегда являются: 1) установки соотнесения современности с прошлым и будущим; 2) парадигмы системы образования и воспроизводства культуры; 3) формы внешнего воздействия других культур, стилей, идеалов и ценностей.

\section{1. Прошлое - современное - будущее}

Потребность "объяснения" с прошлым возникает в Новое время, впервые осознавшим себя "новым", ощутившим историческую дистанцию и непохожесть на античность и средневековье, причем оценившим прошлое в целом негативно: учиться у прошлого особо нечему. Позже, в век Просвещения, отношение к прошлому приобретает иной вид: современность - это необходимый продукт истории; все лучшее, абсолютно истинное существует сейчас, прошлое - лишь подготовка современности. В плане теоретического обоснования этой установки дальше всех шагнул Гегель, и именно гегелевская модель осмысления истории перекочевала затем в "марксизм-ленинизм". Гипноз этой модели оценки прошлого оказался очень силен. В течение нескольких десятилетий поколения советских людей приучались оценивать прошлое как однозначно "темное", будущее - как непременно "светлое", а современность - в плане временных трудностей на пути в "лучшее завтра". Людям слишком долго внушали, что история неизбежно движется "к лучшему", в то время как сама история едва ли это подтверждала.

Нынче, на изломе веков, ощущение того, что слишком многое в жизни не улучшается, а возвращается "на круги своя", уси- 
лилось и окрепло. Грандиозный "научно-технический прогресс" обнаруживает столько издержек, что невольно рождается сомнение: прогресс ли это? С одной стороны, постоянно совершенствуются средства передвижения, коммуникации, производства, средства добычи энергии, средства удобства и комфорта, декларируются идеи свободы, права, гуманности. С другой стороны, все это слишком часто оборачивается против человека, а человечность как таковая попирается в невиданных масштабах. Во всем мире возрастает стремление постичь смысл техногенной практики человечества. Истинно прогрессивные слои мировой общественности озабочены этическими проблемами: поиски измерений добра и зла продолжаются. Мир хочет быть цивилизованным не только со стороны техники и науки.

На этом фоне проблемы нашего общества предстают еще более глубокими и печальными. Мы идем по пути формирования сытой и хорошо одетой "биомассы", которая потребляет материальные блага и нажимает на "кнопки комфорта". Вместо "светлого завтра" главными идеалами стали "мерс" и "мобилка". Почему-то американское общество, не имеющее вековых духовных традиций, стало для нас образцом, хотя на наш взгляд, его утилизированная и прагматическая мораль никогда не сможет стать основой нашего национального и духовного возрождения.

Мы живем в эпоху дефицита духовной культуры. Подобные кризисы возникают в тех случаях, когда нравственная почва истощается или уходит из-под ног, когда люди теряют прочные духовные ориентиры, порывают с вечными ценностями и начинают погоню за сиюминутным. Путь культуры - процесс целостный, органический. Разрывы для него болезненны и пагубны. Нам прежде всего необходимо связать "нить времен", осознать то, что у нас целые поколения были отрезаны от вековых традиций, в том числе этических, религиозных, национальных, языковых, философских, научных и т.д. Общество понесло огромный урон, его культура невероятно обеднела из-за того, что ей был "перекрыт кислород" успокоительным "опиумом": политических и социально-экономических преобразований достаточно, чтобы мир стал иным, чтобы наступило "лучшее завтра". Эта 
иллюзия нам особо дорого обошлась. Само собой ничто не улучшится. Ко всему надо прилагать усилия, тем более в деле сохранения и освоения духовного наследия прошлого, заимствования из него самого прекрасного, достойного, живого и действенного.

Ошибка всех социальных утопий - в утверждении возможности создать такое общество, где торжество добра будет полностью обеспечено самой структурой этого общества. Но так не бывает. Тип социальной системы может только облегчить человеку движение к добру или, наоборот, стимулировать в нем злые начала, но конечный и главный выбор всегда остается за человеком. Лишение человека права выбора, равно как и свободы мышления и творчества, делает его неизменным "винтиком", для которого, собственно, и реализуются шаблоны и стандарты официальной идеологии вместо подлинной духовности.

Самый большой грех большевизма - отсечение прежней духовной культуры "до основания" и воспитание "простого советского человека". (Деспотизм всегда лучше чувствует себя за стеной невежества, в то время как подлинная демократия возможна только в условиях расцвета культуры, свободомыслия, образования.) Большевики, отняв в крестьянской стране землю у крестьян, разрушили материальную культуру страны, а разделив саму культуру на буржуазную и народную, умертвили тем самым жизнь духовную. Пущенная в ход поджигательная идея о "двух культурах", с помощью которой идеологи "развели по углам" народ и интеллигенцию, стала в конечном итоге причиной общего падения уровня культуры. Это падение охватило все слои: "культурный резерв" страны, интеллигент в подростковой шинели - гимназист - стал посмешищем детей из рабочих слободок, откуда получали "путевки в жизнь" павлики морозовы и, в лучшем случае, корчагины; из университетов были вычищены "мятежные профессора", цвет науки, литературы, поэзии, философии, музыки, публицистики был выброшен за пределы страны, и на заброшенной ниве культуры буйно разрослась идеологизированная "полынь". Выросла "своя" интеллигенция с усеченными "вечерними" знаниями рабфаков, с особыми нервами, с "особой" моралью, когда не знания, не развитие, а социальное происхождение и преданность догмам и вождям "решали все". 
Отштампованная по идеологическим матрицам, новая "интеллигенция" (для большего общественного веса названная "трудовой") как нельзя лучше была приспособлена для производства и потребления культурного ширпотреба, получившего название "социалистический реализм".

Большевики фактически срыли высший и самый плодородный слой культуры. Непонимание ими культуры как фактора развития, их подозрительность к интеллигенции проявились еще задолго до захвата ими власти. Еще в 1909 году Ленин и ленинцы яростно и гневно обрушились на сборник статей "Вехи", который был своего рода манифестом русской интеллигенции. Культурная и философская элита - Н.Бердяев, П.Струве, С.Франк, С.Булгаков, Л.Шестов и другие - отрицала классовую борьбу как главный двигатель прогресса, в чем собственно и усмотрели ленинцы главную "ересь", начав одну из самых затяжных кампаний против интеллигенции. Наибольшее негодование большевиков вызывало отношение веховцев к личности, к человеку, в котором они видели главный смысл прогресса. Ленинцев же интересовал не человек, а идея, не личность - а "совокупность общественных отношений". Для веховцев это было пределом аморализма, ибо отсюда прямо вытекало, что человеком можно пожертвовать во имя коммунистического идеала (на деле же оказалось - даже миллионами людей). Философия веховцев была заклеймена как антинаучная и реакционная.

Этот, казалось бы, чисто философский спор оказался впоследствии крайне разрушительным для культуры. Отрицая личность, громя элитарную (названную буржуазной или декадентской) культуру, большевики гасили интеллектуальные звезды на небе собственной страны, а "простые советские" лысенки теснили "элитарных" вавиловых. Элитарность культуры как высшая степень духовности противопоставлялась народности, так как большевики за убогими шорами классовых оценок так и не уяснили, что элитарность ни в коей мере не отрицает народности. Напротив, она включает народную культуру, обогащая ее гением и зрелым талантом.

В странах Европы с подчеркнуто развитой элитарной культурой и уровень массовой культуры значительно выше, чем там, 
где интеллектуальная элита была загнана в подполье. В Европе добротная массовая культура является важным элементом общественного бытия, фактором стабилизации, в лучших своих проявлениях она дает населению те образцы поведения, которых нам так порой не хватает. Не все европейцы витают в высотах культуры, но все они обладают тем "культминимумом", той срединной культурой, которая благотворно влияет на их поведение в обществе и в быту. Человек, приобщившийся к этим стандартам, не станет хамить в автобусе, лезть без очереди в кассу, бросать из окна мусор, гадить в подъездах и лифтах; он будет как минимум опрятно одет и не станет, будучи подшофе, приставать с пустыми разговорами к прохожим на улице и требовать "уважения". Мы гибнем не столько от массовой культуры, сколько от того, что за годы советской власти у нас разрушены все уровни и стандарты культуры, включая народную, от того, что исчерпался тот интеллектуальный и нравственный потенциал, который был накоплен многовековым трудом и общим восхождением культуры.

Кроме всего названного, сам культ будущего, ставший своего рода религией советского общества, был глубоко унизителен и вреден для человека. Человек рожден, чтобы реализоваться в собственной, настоящей жизни. Он должен чувствовать себя самодостаточным в свое собственное, отпущенное ему природой время. Если в настоящем усваивается мысль, что человек будущего лучше нас уже в силу того, что он человек будущего, то мы в настоящем все равно хуже, чем могли бы быть, и стоит ли стараться нам быть лучше сейчас, если все, что мы делаем, будет другими сделано лучше. Для подлинной духовности, как и для искусства, нет "прошлого". Оно есть для науки и техники, а не для самих основ жизни. Главная наша беда - размывание нравственных ценностей, без которых слабеют все духовные основы.

\section{2. Узкоспециализированное и усредненное образование "винтиков"}


Отсечение "вредной" элитарной культуры, как культуры богатых или идеологически "неверных", сопровождалось коренным изменением всей концепции образования, в которой уже не находилось места обязательной глубокой гуманитарной подготовке личности. На наш взгляд, из всех систем образования, которые существовали в разные времена у разных народов, самой совершенной и эффективной является система Царскосельского лицея. Также и по мнению некоторых зарубежных специалистов, лучшей системы образования человечество пока не придумало. Главное достоинство этой системы - сильнейшая гуманистическая направленность. Для воспитанников Лицея обязательным было изучение родной и мировой истории, литературы, философии, языков, музыки, живописи и т.д. Такая концепция образования способствовала развитию чисто человеческих качеств: патриотизма, порядочности, умения сопереживать, отличать добро от зла. А уже на этом мощном гуманистическом фундаменте шло впоследствии формирование специалистов различных направлений - ученых, инженеров, писателей, деловых людей. Усвоение общечеловеческих ценностей позволяло им гораздо объемнее, шире, глубже воспринимать окружающий мир. Разностороннее гуманистическое образование способствовало воспитанию сначала личности, гражданина, а потом уже специалиста.

Цель, которой служило все советское образование - усреднение личности - была, по сути, аморальной целью, ибо официальная власть была заинтересована в формировании серой послушной массы, в недрах которой нельзя было бы различить ни наций, ни социальных слоев, ни различных мировоззрений, ни философских течений. "Моральный кодекс строителя коммунизма" должен был быть единым для всех, а усвоение его шло через всю систему средней и высшей школы, через прессу, через комплекс партийной учебы, политинформации в трудовых коллективах и т.д. Впитывание основных новокультурных стандартов шло в готовом виде, без собственного напряжения мысли, без поисков, колебаний, страданий и сомнений, без всего того, что всегда способствовало становлению и восхождению души. Но никакие планы и программы коммунистического воспита- 
ния, лобовой атаки на душу и совесть не смогли заменить того, что должно было ненавязчиво прививаться человеку с детства; никакой бой барабанов не дал той воодушевленности и свободы, которая рождается в глубинах души, если эта глубина осмысливается, поглощает саму суть человека, не давая торжествовать одним лишь инстинктам.

На этом фоне идеологического и морального усреднения узкая специализация людей-"винтиков" выглядела настоящим благом. "Узкие" специалисты должны были заменить ненадежную дореволюционную интеллигенцию. На место носителей общей духовности народа были поставлены наспех подготовленные "выдвиженцы". Лозунг "Кадры решают все" стал фатальным. "Узко" специализированные кадры знали, как правило, лишь то, что им было предписано знать, они слабо ориентировались даже в смежных специальностях. Потребности в более широком кругозоре "кадры" не испытывали, ведь гарантом успеха и уважения были не знания, а идейная твердость. А поскольку никакой рабфак не мог сравниться даже с дореволюционной гимназией или реальным училищем, то снизу доверху в новой хозяйственной системе "кадрам" не хватало ни дальновидности, ни глубины понимания экономических и политических действий, ни способности анализировать события и их последствия. Три поколения советских людей учились мыслить и действовать только в рамках "своей" специальности, с ориентацией на план, вал, пятилетку, соцсоревнование. Потому с легкостью уничтожались леса, поворачивались реки, губились земли, а вслед за ними - и совесть, и мораль, и культура.

Узкоспециализированное образование не приобщало к культуре высокого мышления, оно лишь формировало прагматизм. Прагматизм отчета, рапорта, показателей. Отсутствие культуры мышления плодило бескультурье действия, бескультурье жизни.

"Специалист подобен флюсу", - говорил Козьма Прутков. Но сегодняшний информационно-технический мир требует специалистов совершенно иного класса и качества. Мир стал намного теснее, чем когда-либо: в нем быстро движутся машины, приборы, информация, деньги, товары, люди. Социальные, политические, экономические, информационные связи становятся 
тотальными - в этом плане мир давно уже перерос какую-либо "специализацию". Понимать современное бытие в его целостности и совокупности разнообразных форм - вот что прежде всего должен уметь современный специалист, чтобы верно оценивать все возможности и перспективы, полностью осознавать свою включенность в мир и свою ответственность в нем. Определяющими критериями прогресса должны считаться не технические или научно-технологические параметры и не политические или социальные идеалы, а морально-этические и гуманистические измерения. Чтобы достичь этого, необходимо внедрить в жизнь новую, гуманистически-ориентированную концепцию образования. Каждому нормальному и свободному человеку необходимо знакомство с опытом решения вечных проблем человечества, связанных с пониманием самого мироздания, различных версий картин мира, осмыслением феномена человека, его места в космосе и социуме, в современной социобиотехносфере; с размышлениями о смысле жизни и смерти, о смысловых комплексах, регулирующих деятельность людей, в частности познавательную деятельность и так далее. Охватить проблемы и перспективы современной мировой цивилизации, коэволюции природы и человечества, информационно-технического общества в историческом и аксиологическом измерениях - вот к чему должен стремиться истинный высокообразованный специалист. Упрощенное образование не дает целостного мировосприятия, а это оборачивается сначала духовными, а потом "узкоспециализированными" экологическими, техногенными, экономическими и любыми другими катастрофами.

Прежняя узкая специализация срабатывала как узколобость, которая повлекла за собой (под лозунгом борьбы с пережитками прошлого) социальное и физическое уничтожение носителей духовности, а затем - самой духовности путем подмены общечеловеческих моральных ценностей ценностями узкоклассовыми. Упрощение образования, искоренение в нем нравственных и духовных начал, классовая агрессивность ("мы вас похороним"), разгром национальных культур - это не случайность и даже не ошибка. Это - закономерность крестового похода недообразованных люмпенов и невежества политических авантюристов 
против религии, культуры, национальных традиций, то есть всего того, что оказалось непостижимым для "узкоспециализированного" мировоззрения "новых кадров".

\section{3. "Простой" (бывший советский) человек и "навозная жижа" с Запада}

Вся история нашего тоталитаризма - это история торжества революционной воли и воинствующего невежества. Если на средних уровнях управления полузнайство "узкоспециализированных" кадров грозило по меньшей мере недальновидностью, то на верхних - оборачивалось некомпетентностью катастрофических масштабов: поворотами рек, уничтожением Арала, антиалкогольным законом, Чернобылем... Но главное все же - не события и не вещи, а "качество" людей их творящих. Если не брать в расчет "руководящие кадры", а взглянуть на "народ", то тоже утешения мало. Народ - это большинство людей, проживающих в "спальных" микрорайонах городов, которые даже не понимают всего ужаса своего положения и глубины собственного несчастья. Они утратили связь с землей, с вековой народной культурой, обычаями, моралью, фольклором. Их выдавили из села сначала коллективизация, потом хрущевские укрупнения, потом перестроечный беспредел. А попав в города, на заводы, в конторы, ни они, ни их дети, ни уже внуки так и не приобщились к культуре мировой: через театры, музеи, университеты, гармонию архитектурной среды, ибо все их время заполнял труд, заработки с которого все никак не давали жить комфортно, богато и свободно. Образования в лучшем смысле (без идеологического каркаса) люди были лишены. Добротной, "срединной" массовой культуры не сложилось, более или менее налаженный быт отождествлялся с мещанством, считался неприличным для пролетарской "простоты". Стремление заработать "большие деньги" встречало осуждение, а приветствовалось лишь желание ехать "за туманом и за запахом тайги". В итоге ценность труда была попрана. "Светлое завтра" все не наступало, коммунистические идеалы постепенно блекли, энтузиазм слабел, вера выветривалась. Люди стали жертвами собственной простоты. 
Удел большинства - домино, карты, выпивка, примитивный флирт, кино (разумеется, не Тарковский) и музыка (опять же не Бетховен и не Чайковский, а такая, что просто убивает тишину). Удивительно, но именно тишины больше всего боятся "простые" люди, потому что она оставляет их один на один с собственной душевной опустошенностью, духовным обнищанием. Литература и искусство доступны им только в самых заниженных проявлениях. Религия вызывает насмешки и скептицизм, философия кажется смертельно скучной. Лишь наука воспринимается с инстинктивным уважением.

Наиболее грустное: опустошенные люди с неразвитыми способностями, обессиленные трудом, обворованные государством и "новыми" дельцами, утратившие надежды дождаться хоть какого-нибудь улучшения жизни, воспитывают себе подобных. Дети даже не достигают уровня развития и морали родителей, который и без того нельзя считать высоким. Родителям было присуще хоть какое-то чувство порядочности, честности, собственного достоинства, отзывчивости, гуманности. Нынче же ценности измельчали до предела, а компьютерная грамотность детей их не заменяет. Работающим матерям (а социалистическое производство не смогло обойтись без женского труда, введя систему низких ставок и окладов для мужей, чтобы, не дай бог, не разбогател рабочий люд) нет времени учить своих детей языкам, музыке, этикету. Если детям все же хотят дать наилучшее образование, самореализоваться в них, то это осуществляется за счет каких-то сверхусилий всех родственников, сверхнагрузки для всех. И все же, надо отдать должное, среди женщин намного больше состоявшихся личностей, чем среди мужчин. Отцы, которые комплексуют по поводу того, что никаким честным трудом невозможно самому содержать семью, все чаще начинают давать негативные примеры своим детям (воровство, махинации, просто пьянство). Они часто сознательно самоустраняются от процесса воспитания детей, вполне серьезно полагая, что тех "научит жизнь". А вокруг все еще нет достойной жизни, которая бы учила добру. Дети привыкают к заниженным нормам бытия, к поломанным заборам, к поцарапанным стенам и лифтам с классическими "трехзначными формулами". 
Наше социальное бытие требует нового качества экономики, политики, духовного производства. Одолеть кризис духа одной системе образования не под силу: знания не заменяют воспитания.

Прежнее упрощенное, узкоспециализированное образование вкупе с мощным идеологическим прессингом породили тип "простого советского человека". А когда начал подниматься "железный занавес", который отгораживал советское общество от мировой культуры, "простые" люди начали с восторгом знакомиться не с истинными образцами и достижениями мирового творчества, а (по выражению Александра Солженицына) с "навозной жижей", которая подтекла под "железный занавес" первою. Не приходится удивляться, что массы оказались неспособными к восприятию шедевров, их уровень простоты соответствовал лишь способности потребления "отходов" культуры: они смогли позаимствовать не демократическую раскованность и свободомыслие, а распущенность и культ низких наслаждений и развлечений. Как заметил когда-то в одном из интервью известный мыслитель и религиозный деятель Александр Мень, мы перепутали краны и вместо водопровода присоединились к канализации мировой культуры. Он тогда напомнил, как во II веке до нашей эры в Рим стали проникать греческие влияния, что привело в ужас римлян старого закала. Их соотечественники соприкоснулись с Элладой времен упадка. Они получили от нее не столько Платона или Софокла, сколько "отходы культуры", распущенность нравов, скептицизм, безверие, культ удовольствий и развлечений. Нечто подобное произошло и в нашем контакте с мировой культурой.

Для нашего общества особенно опасно наложение "мирового навоза" на комплекс "простого" человека, который еще долго будет держаться в среде истинных тружеников. Сама "простота" - вещь весьма сложная: простым называют и гениальное и примитивное. Наша простота - явно не от гениальности и не от большого ума. Наша простота - результат отречения от собственных духовных традиций, от культуры, названной "буржуйской", "мещанской", осужденной узколобой идеологией "пролетариев, которым нечего терять". 
Уже и правда нечего терять, уже почти забыто то, чем надлежит дорожить каждому народу, а "заместительная терапия" из отходов западной, преимущественно прагматической и потребительской американской, культуры не вдохновляет и не обеспечивает духовного оздоровления общества. Дичаем... Только когда все это поймут, "объевшись" боевиками, эротикой с монстрами, мутантами, киборгами, виртуальными уродцами даже в детских мультиках, только тогда появится надежда и станет возможным духовное возрождение нации. Но сам по себе процесс "к лучшему" не пойдет, необходима кропотливая работа каждой души во имя ее собственного восхождения из бездны и темноты к вершинам и свету.

Потенциал культуры исчерпывается дольше, чем экономики или политики, но и он имеет свои пределы. Деградация культуры затронула все: власть, науку, армию, образование, милицию, кино и т.д. Причина одна - это вирус антиинтеллектуализма, запущенный большевиками, питающийся нынче столь доступной и повсеместной "навозной жижей", вершит свое дьявольское дело.

Духовность, однако, никогда не умирает. Просто ее поток часто бывает загнанным глубоко "в недра", если нормальное ее существование и воспроизводство невозможно на поверхности мировоззренческого поля, или когда ее плавное течение перебивается водопадом чужеродной культуры, несущей иные ценности, идеалы, стили. Но ситуация все равно остается тревожной: моральные нормы продолжают снижаться несмотря на возрастание уровня автоматизации жизни и количества "кнопок комфорта". И очень проблематичными выглядят все старания нашего национального возрождения и демократического независимого будущего. 